\title{
Project management assets and their relationship with the project management capability of the firm
}

\author{
Kam Jugdev ${ }^{\text {a,b,*, Gita Mathur }}{ }^{\mathrm{c}, 1}$, Tak Shing Fung ${ }^{\mathrm{d}, 2}$ \\ ${ }^{a}$ Project Management and Strategy, Centre for Innovative Management, Athabasca University, 8311-11 Street SW Calgary, Alberta, Canada T2V 1N7 \\ ${ }^{\mathrm{b}}$ Schulich School of Engineering, University of Calgary, 8311-11 Street SW Calgary, Alberta, Canada T2V 1N7 \\ ${ }^{\mathrm{c}}$ Department of Organization and Management, College of Business, San José State University, Business Tower 564, One Washington Square, \\ San José, CA 95192-0070, USA \\ d Information Technologies, University of Calgary, 2500 University Drive, Calgary, Alberta, Canada T2N 1 N4
}

Received 13 June 2006; received in revised form 9 December 2006

\begin{abstract}
According to the Resource Based View of the firm, strategic assets contribute to a firm's competitive advantage. Strategic assets are characterized as Valuable, Rare, Inimitable, and they involve Organizational Support. These four characteristics have been theorized to result in competitive parity, temporary competitive advantage, or a sustainable competitive advantage for a company. This paper examines the relationships between key project management assets and these project management process characteristics using data from a survey of North American Project Management Institute ${ }^{\circledR}$ members. Findings from an analysis of the data suggest that intangible project management assets are a source of temporary competitive advantage while tangible project management assets are not. These findings highlight the importance of identifying and managing intangible project management assets for practitioners and scholars of project management.
\end{abstract}

(C) 2007 Elsevier Ltd and IPMA. All rights reserved.

Keywords: Competitive advantage; Multivariate analysis; Project management; Resource Based View; Strategic assets; Strategy

\section{Introduction}

Project management, including the tools, techniques, and knowledge-based practices applied to manage the creation of products and services, is becoming an increasingly accepted and applied discipline across industry sectors. This paper is motivated by the belief that practitioners and scholars of project management can benefit from understanding how project management can be leveraged

\footnotetext{
${ }^{*}$ Corresponding author. Address: Project Management and Strategy, Centre for Innovative Management, Athabasca University, 8311-11 Street SW Calgary, Alberta, Canada T2V 1N7. Tel.: +1 403301 2956; fax: +1 4033012986.

E-mail addresses: kamj@athabascau.ca (K. Jugdev), mathur_g@ cob.sjsu.edu (G. Mathur), tfung@ucalgary.ca (T.S. Fun).

${ }^{1}$ Tel.: +1 408924 3553; fax: +1 4089243555 .

${ }^{2}$ Tel.: +1 403220 6941; fax: +1 4037308107 .
}

as a source of competitive advantage for a company. To this end, the paper presents an analysis of the relationship between key project management assets and the project management capability of the firm drawing on the Resource Based View of the firm from the field of strategic management and using data gathered from an online survey of a random sample of North American Project Management Institute ${ }^{\circledR}$ members.

In the Resource Based View of the firm, a company has a bundle of assets (resources) such as human resources (individual skills and knowledge), financial resources (money), physical resources (equipment), social resources (network of contacts), and organizational resources (structure, processes, and relationships) [1]. Assets can be tangible (concrete and physical) or intangible (tacit, unspoken but understood; e.g., knowledge-based assets) [2]. Only a subset of a company's assets, classified as strategic assets, 
is a source of its competitive advantage [3]. These strategic assets that contribute to competitive advantage involve explicit and tacit knowledge [4-7] that is embedded in a company's unique internal skills, knowledge, resources, and ways of working $[8,9]$.

The VRIO framework of competitive advantage has emerged from this perspective as a useful way of characterizing strategic assets $[10,11]$. In this framework, strategic assets are those assets which are Valuable (economically important, that is, they make money for the company), Rare (unique, meaning that few companies have these resources), Inimitable (hard to copy, meaning that it can be costly to duplicate them and difficult to figure out what other companies are doing to have such strategic assets), and they have Organizational Support (strong management support and processes and systems to support the assets).

This paper reports on findings from a study that was designed to examine project management using the Resource Based View of the firm and the VRIO framework. It addresses the following question: How are tangible and intangible project management assets related to the project management capability of the firm? Tangible and intangible project management assets are the independent variables and project management capability is the dependent variable in this paper. Drawing on the VRIO framework, process capability is defined in this study as the achievement of the characteristics valuable, rare, inimitable, and having organizational support in the project management process (VRIO characteristics).

The sections of the paper that follow provide an overview of the literature, a theoretical model and associated hypotheses linking project management assets to the achievement of VRIO characteristics of the project management process, the data collection and analysis methodology, a discussion of the results, conclusions, and the implications of the findings for practice and future research.

\section{Literature review}

The Resource Based View of the firm is emerging as a dominant approach in the strategy literature. The Resource Based View of the firm and the VRIO framework that is based on it have been used in a number of empirical studies [12-16]. In 2005, the Academy of Management indicated that over 200 academic papers were published using the Resource Based View. Project management is a new field that is a long way from developing its own theory, so it draws from the field of management $[17,18]$. The project management literature review revealed few empirical studies on project management as a strategic asset [19], and there are few empirical studies on knowledge management in the project management context [20]. This work to explore the sources of competitive advantage that can be leveraged from project management is situated within the VRIO framework.
In the VRIO framework, competitive advantage is conceptualized to have several levels [11,10]. A company achieves competitive parity when it has resources that are valuable. Competitive parity means that a company is making normal profits, as are its competitors. A company achieves a temporary competitive advantage when it has resources that are both Valuable and Rare. The competition can, however, eventually acquire these rare resources. A company achieves a sustained competitive advantage when it has resources that are Valuable, Rare, and Inimitable. A sustained competitive advantage means that the company is making above normal profits through resources that the competition cannot copy or understand. In the VRIO model, as a company moves from competitive parity, to a temporary competitive advantage, to a sustained competitive advantage, there is increasing evidence of Organizational Support in relation to these resources. A company is at a competitive disadvantage when it does not have resources that are Valuable, Rare, Inimitable, or involve any Organizational Support.

Project management involves practices applied on a project to deliver a result, product, or service [21] based on tangible and intangible assets $[19,20]$. Tangible assets are concrete and based on codified or explicit knowledge, whereas intangible ones are based on tacit knowledge. Codified and tacit knowledge have also been labelled as "know-what" and "know-how" [7] in the knowledge management literature. Most of the project management literature has focused on the tangible assets and codified knowledge as shared through project management offices, methodologies, and tools and techniques [22,23]. An examination of these tangible assets indicates that while valuable, they are not rare or inimitable and therefore do not meet the VRIO criteria for sources of competitive advantage [24]:

- An investment in project management methodologies helps companies achieve some degree of project success. Methodologies provide guidelines and checklists to ensure that practices are being followed properly and that the right outcomes are being attained. Although valuable, such methodologies are readily available and imitable.

- Investments in physical, technological, and financial project management assets are also valuable. Throughout a project, technology (including hardware and software) is often used as part of the project infrastructure to help improve information and knowledge flow and to assist with the decision-making process (e.g., project management information systems, knowledge management systems, and executive decision tools). The array of physical tools and techniques are readily available and not rare or unique.

- A number of project management associations develop bodies of knowledge to guide practitioners [21]. These project management bodies of knowledge are valuable and provide explicit standards on practice in the knowl- 
edge areas of time, cost, scope, quality, human resources, risk, communications, procurement, and integration [25]. The bodies of knowledge are not rare.

- Increasingly, companies are establishing project management offices to coordinate the use of tools, techniques, and technology to support projects, to ensure consistency of use, and to provide training and guidance, particularly on troubled projects [26-28]. Project management offices may provide the project management methodology to be used, specify project templates, conduct project audits, and even serve as reporting centres. Project management offices reflect a coordinated and structured way of implementing tangible project management assets. The tools, techniques, and practices that project management offices use can be readily purchased and are easily transferred between companies, particularly as people move from one organization to another. Project management offices are valuable, but their practices are far from rare, as numerous methodologies, templates, and guidelines can be downloaded from Internet sites.

- The emphasis on codified and tangible assets in project management is made clear by the focus on project management maturity models in the literature [29-32]. These models consist of progressive stages of increasingly defined and repeatable, codified processes and practices.
Evidence that maturity models improve a company's return on investment is weak and the models do not address intangible assets [33].

In order to explicitly leverage project management as a strategic asset, the literature review indicates that there is a need for improved understanding of the factors that constitute the tangible and intangible assets of project management and the relationship between these assets and competitive advantage. It appears that companies need to identify and cultivate their intangible project management assets to make this capability rare and inimitable and therefore a source of competitive advantage. The remainder of the paper reports on research that was motivated by this need. The paper makes a contribution to the growing body of empirical works on strategic assets and project management.

\section{Theoretical model}

A theoretical model was developed for this study drawing on the literature from the Resource Based View of the firm and the VRIO model. The theoretical model links the inputs, outcomes, and intermediate variables of interest for this study and is presented in Fig. 1.

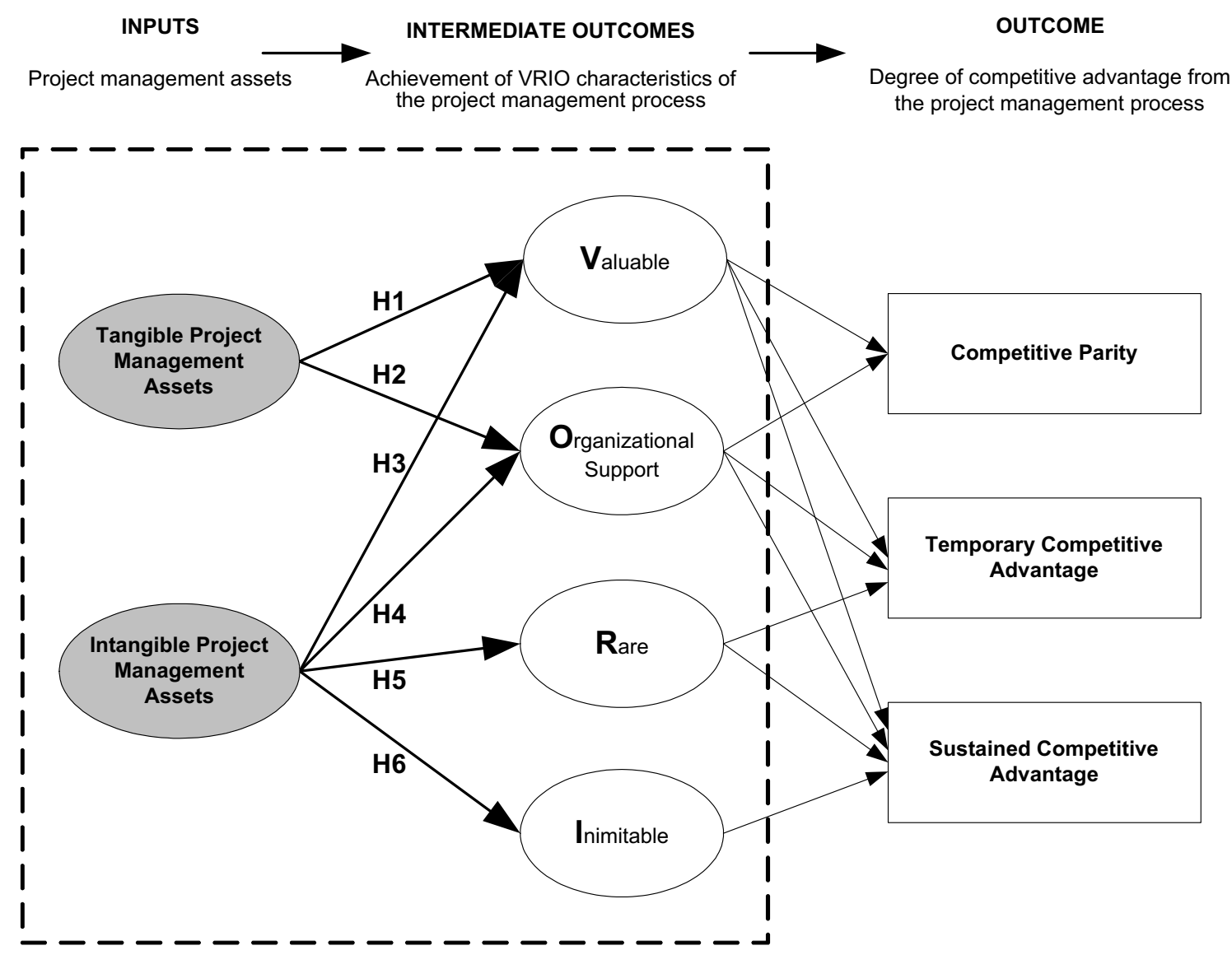

Fig. 1. Theoretical model linking the determinants and outcomes of the VRIO characteristics of the project management process. 
The inputs of interest are the tangible and intangible project management assets. Not all assets will be a capability that results in a competitive advantage. The outcome of interest is the degree of competitive advantage obtained from the project management process (competitive parity, temporary competitive advantage, or a sustained competitive advantage). The achievement of VRIO characteristics (project management capability) are intermediate outcomes through which project management assets determine the degree of competitive advantage obtained from the project management process.

The arrows in the model between the inputs and intermediate outcomes and the intermediate outcomes and outcome present the hypotheses from the literature. Tangible project management assets are expected to affect the extent to which the project management process is Valuable and has Organizational Support. Such assets are not rare and are imitable. Intangible assets are expected to affect the extent to which the project management process is Valuable, Rare, Inimitable, and has Organizational Support. These relationships between tangible and intangible assets and the intermediate outcomes (the VRIO characteristics) have not been addressed in the context of project management in the literature. We provide these as hypotheses of central interest to this study below. Later in the results section, we elaborate on these hypotheses using specific factors extracted from our data on project management processes which define the independent variables (tangible and intangible assets).

Hypothesis 1: Tangible project management assets will result in the project management process being Valuable (V).

Hypothesis 2: Tangible project management assets will result in the project management process having Organizational Support $(O)$.

Hypothesis 3: Intangible project management assets will result in the project management process being Valuable $(V)$.

Hypothesis 4: Intangible project management assets will result in the project management process having Organizational Support $(O)$.

Hypothesis 5: Intangible project management assets will result in the project management process being Rare $(R)$. Hypothesis 6: Intangible project management assets will result in the project management process being Inimitable $(I)$.

\section{Data collection and analysis methodology}

Data were collected on the variables of interest, tangible and intangible project management assets and associated VRIO characteristics of the project management process using a structured survey instrument. The survey design closely followed the format recommended by experts in the field [34-36]. Questions were developed for each vari- able using multiple-item $(3-14$, average $=8$ items per variable). We based the questions on the findings from an earlier extensive qualitative study of four international companies to assess project management practices [24]. The measures were based on the literature and refined with a pilot study. Likert-scales, appropriate for perception-oriented questions were used in this study and were based on a seven-point scale with the end points being Strongly Agree and Strongly Disagree. Retrospective bias was avoided by framing questions in the context of the past year. While data was reported by individual participants, the unit of analysis was an organization's project management process.

The survey was pre-tested online to ensure that all the main topics were covered in the survey. The survey was then conducted using the Internet, targeting a representative, random sample of North American Project Management Institute ${ }^{\circledR}$ members. The response rate was $10.1 \%$, 202 participants out of 2000 targeted individuals. This sample size is considered "fair" for an exploratory factor analysis because the ratio of sample size (202) to the number of variables (80) was less than 5:1 [37]. Data was coded using a data dictionary and items were reverse-coded as appropriate. Means at the subscale level were used in place of missing data. We analyzed non-response bias by conducting Chi squared tests on the participants and the original mailing list of 2000. There was no gender bias related to the response rate (Males: 116, 8.9\%; Females: 67, 9.9\%) versus the non-response group (Males: 1190, 91.1\%; Females: $608,90.1 \%), \chi^{2}(1)=0.578, p=0.462$ which is not statistically significant. Additional demographic information on the respondents follows:

- About $60 \%$ of the participants were from the United States and the rest from Canada.

- The male-to-female participant ratio was nearly 2:1.

- Two-thirds of the participants were between 30 and 49 years of age.

- Nearly three-quarters of the participants had their $\mathrm{PMP}^{\circledR}$ designation.

- Participants were well-educated, with over $90 \%$ at the undergraduate or higher level.

- Most participants were in middle management positions or technical roles.

- About one-third of the participants had 6-9 years of experience, and about another third had 10-19 years of experience. About two-thirds of the participants had been with their current company for less than 9 years.

- $61 \%$ of the participants were in the top four industries: information industry $(23.0 \%)$; scientific and technical services industry (16.4\%); finance and insurance industry $(12.0 \%)$; manufacturing industry $(9.8 \%)$.

Exploratory factor analysis [38] using $\operatorname{SPSS}^{\circledR}$ v. 13.0 was used to extract factors for the independent variables (tangible and intangible project management assets iden- 
tified and defined as project management factors) and for the dependent variables (achievement of VRIO characteristics defined as VRIO factors). These are latent constructs which cannot be measured directly [39]. We analyzed the data using both the orthogonal rotation (varimax) and non-orthogonal rotation (oblimin) on the independent variables and dependent variables. The varimax rotation technique gave us a more interpretable solution. We therefore proceeded using varimax rotation and 0.40 as a cut-off to identify items with high loadings for inclusion with each factor. Eigenvalues greater than one were used to extract reliable factors. Cronbach's alpha measures how well a set of items measures a single unidimensional latent construct. A reliability coefficient of 0.70 or higher is acceptable in the social sciences [40]. We used this test to assess the internal consistency of the items within each construct. In addition we looked for factors consisting of three or more items. Our starting model had eight factors for the independent variables and five factors for the dependent variable. We extracted six factors for the independent variables and three factors for the dependent variable based on the requirement of three or more items. The results are summarized in the section that follows.

Structural equation modelling was performed using LISREL $^{\circledR}$ v. 8.54 to assess the multivariate relationship between the project management factors and the VRIO factors identified through the exploratory factor analysis. The sample size of 202 was adequate for a small-to-medium sized model [37].

A copy of the complete survey instrument is available upon request.

\section{Discussion of results}

This section discusses the factor analysis results, the correlations between the emergent factors, and the structural equation model linking these factors.

\subsection{Factor analysis results}

Four project management factors were identified for the independent variables, three representing tangible assets and one representing intangible assets. Labels used below for these four factors reflect the items in each factor. These four factors explained $52 \%$ of the total variance of the original variables. These four factors are listed below.

1. Project management maturity (tangible) reflected the use of project management practices (e.g., a project management office, tools and techniques, methodology, standards, and processes), the use of program and portfolio management practices, and the addressing of the efficiency and effectiveness of practices (14 items; Cronbach's Alpha of 0.953; explains 14.1\% of variance).
2. Sharing know-how (intangible) included the different ways in which tacit knowledge was shared (e.g., sharing knowledge informally, mentoring, stories, brainstorming, and shadowing) (11 items; Cronbach's Alpha of 0.867 ; explains $13.1 \%$ of variance).

3. Training and development (tangible) involved managerial support for training and development and included development of project manager competences, support for PMP $^{\circledR}$ certification, and a career path for project managers ( 8 items; Cronbach's Alpha of 0.931 ; explains $12.5 \%$ of variance).

4. Sharing know-what (tangible) included codified knowledge-sharing practices and reflected the use of databases, systems, intranets, best-practices databases, and processes for sharing knowledge (7 items; Cronbach's Alpha of 0.939; explains 11.9\% of variance).

The emergence of the second independent factor (Sharing Know-How) is a significant finding of this research, highlighting the importance of tacit knowledge in a discipline where there is a focus on tangible factors and a prevalence of codified project management practices.

Two additional factors were extracted as independent variables. These two factors represent undervalued sharing of know-how and knowledge and correspond to the lack of practices, incentives, and support for sharing know-how and knowledge. While these two factors explained an additional $7.3 \%$ and $5.1 \%$ of the variance respectively, they had a lower number of items and Cronbach's Alpha compared to the four asset factors. We, therefore, did not include these two factors in our examination of the relationship between project management assets and project management process capabilities.

Three factors were identified that comprised the dependent variable (achievement of the VRIO characteristics in the project management process). These were Valuable, Rare, and Organizational Support. A fourth expected characteristic from the VRIO framework, Inimitable, did not emerge as a factor because it consisted of only two items and the Cronbach's Alpha was low. The item that describes project management as difficult to copy was, however, found included in the Rare factor, leading to the tentative conclusion that there is an overlap between these two, Rare and Inimitable characteristics of project management assets [41]. The remaining three factors explained $55 \%$ of the total variance of the original variables. These three factors are listed below.

1. The Valuable factor involved survey items on project management providing economic value (e.g., improving business performance, increasing profitability, and responding to environmental threats and opportunities) (9 items; Cronbach's Alpha of 0.929; explains 25.1\% of variance). 
Table 1

Correlation coefficients ${ }^{\mathrm{a}}$ between emergent factors

\begin{tabular}{|c|c|c|c|c|c|c|c|}
\hline & & 1 & 2 & 3 & 4 & 5 & 6 \\
\hline 1 & $\begin{array}{l}\text { Project } \\
\text { Management } \\
\text { Maturity }\end{array}$ & & & & & & \\
\hline 2 & $\begin{array}{l}\text { Sharing } \\
\text { Know-How }\end{array}$ & $.601^{* * *}$ & & & & & \\
\hline 3 & $\begin{array}{l}\text { Training and } \\
\text { Development }\end{array}$ & $.744^{* * *}$ & $.489^{* * *}$ & & & & \\
\hline 4 & $\begin{array}{l}\text { Sharing } \\
\text { Know-What }\end{array}$ & $.705^{* * *}$ & $.539^{* * *}$ & $.635^{* * *}$ & & & \\
\hline 5 & Valuable & $.690^{* * *}$ & $.577^{* * *}$ & $.565^{* * *}$ & $.471^{* * *}$ & & \\
\hline 6 & $\begin{array}{l}\text { Organizational } \\
\text { Support }\end{array}$ & $.786^{* * *}$ & $.489^{* * *}$ & $.658^{* * *}$ & $.686^{* * *}$ & $.666^{* * *}$ & \\
\hline 7 & Rare & $.307^{* * *}$ & $.380^{* * *}$ & $.226^{* *}$ & $.243^{* * *}$ & $.255_{* * *}$ & $.240^{* * *}$ \\
\hline
\end{tabular}

2. The Organizational support factor involved survey questions on management support, adequate resources for the discipline, and project management being an organization-wide undertaking (10 items; Cronbach's Alpha of 0.841 ; explains $21.3 \%$ of variance).

3 . The Rare factor involved survey items that showed project management to be unique, controlled by a few firms, and difficult to copy (3 items; Cronbach's Alpha of 0.690 ; explains $8.7 \%$ of variance).

The rotated component matrices from the factor analysis are available in a prior publication [42].

\subsection{Correlations between emergent factors}

The correlation coefficients between the seven factors that emerged from the factor analysis are shown in Table 1.

Correlations between 0 and 0.20 show weak to negligible relationships; correlations between 0.20 and 0.40 show weak to low relationships; correlations between 0.40 and 0.70 reflect moderate relationships; correlations between 0.70 and 0.90 show strong and high relationships; and correlations between 0.90 and 1.0 reflect very strong and very high relationships [43].

All fours project management asset factors correlate positively and significantly with all three VRIO factors. These findings are in line with the theoretical expectations of the VRIO framework. The high correlations observed among the asset variables would point to the need for extensions of the VRIO framework that explore the moderating influence of one or more asset factors on the relationship between the other asset factors and the outcomes. This is beyond the scope of the current paper.

\subsection{Structural equation model}

In the theoretical model presented in Fig. 1, the six hypotheses stated define the relationship between tangible and intangible assets and the four VRIO characteristics. These six hypotheses are further elaborated in the emergent structural model in Fig. 2 when linking the four project management asset factors (Project Management Maturity, Training and Development, Sharing Know-What, and Sharing Know-How) and three VRIO factors (Valuable, Organizational Support, and Rare).

The project management factors that represent tangible project management assets are shown in solid grey ovals and the one that represents intangible project management assets is shown in a dotted grey oval. The VRIO factors are represented using solid white ovals. The solid arrows show hypothesized and empirically supported relationships $(\mid$ t-statistic $\mid>2)$ and the dashed arrows show hypothesized but not empirically supported relationships. The absence of a line between variables implies a lack of a hypothesized effect. Path coefficients and $t$-values are provided for each significantly path in Fig. 2. Five of the nine paths corresponding to the hypotheses $\mathrm{H} 1 \mathrm{a}, \mathrm{H} 2 \mathrm{a}, \mathrm{H} 2 \mathrm{c}, \mathrm{H} 3$, and $\mathrm{H} 5$ were empirically supported in our study:

H1a: Project Management Maturity significantly predicts the project management process being Valuable (supported).

H1b: Training and Development significantly predicts the project management process being Valuable (not supported).

H1c: Sharing Know-What significantly predicts the project management process being Valuable (not supported). H2a: Project Management Maturity significantly predicts the project management process having Organizational Support (supported).

H2b: Training and Development significantly predicts the project management process having Organizational Support (not supported).

H2c: Sharing Know-What significantly predicts the project management process having Organizational Support (supported).

H3: Sharing Know-How significantly predicts the project management process being Valuable (supported).

H4: Sharing Know-How significantly predicts the project management process having Organizational Support (not supported).

H5: Sharing Know-How significantly predicts the project management process being Rare (supported).

Three practical measures of fit were used to evaluate the adequacy of the model: the goodness-of-fit index (GFI values greater than 0.90), the adjusted goodness-of-fit index (AGFI values greater than 0.80), and the root mean squared of residuals (RMSR values less than 0.10). A resulting GFI of 0.969 , AGFI of 0.858 , and RMSR of 0.032 , indicate that the model provides an adequate fit for the data.

Project Management Maturity significantly predicts the project management process being Valuable as expected, but contrary to expectations, Training and Development and Sharing Know-What did not. In project management maturity models, training and development and sharing 
INPUTS

Project management assets
INTERMEDIATE OUTCOMES

Achievement of VRIO characteristics of the project management process
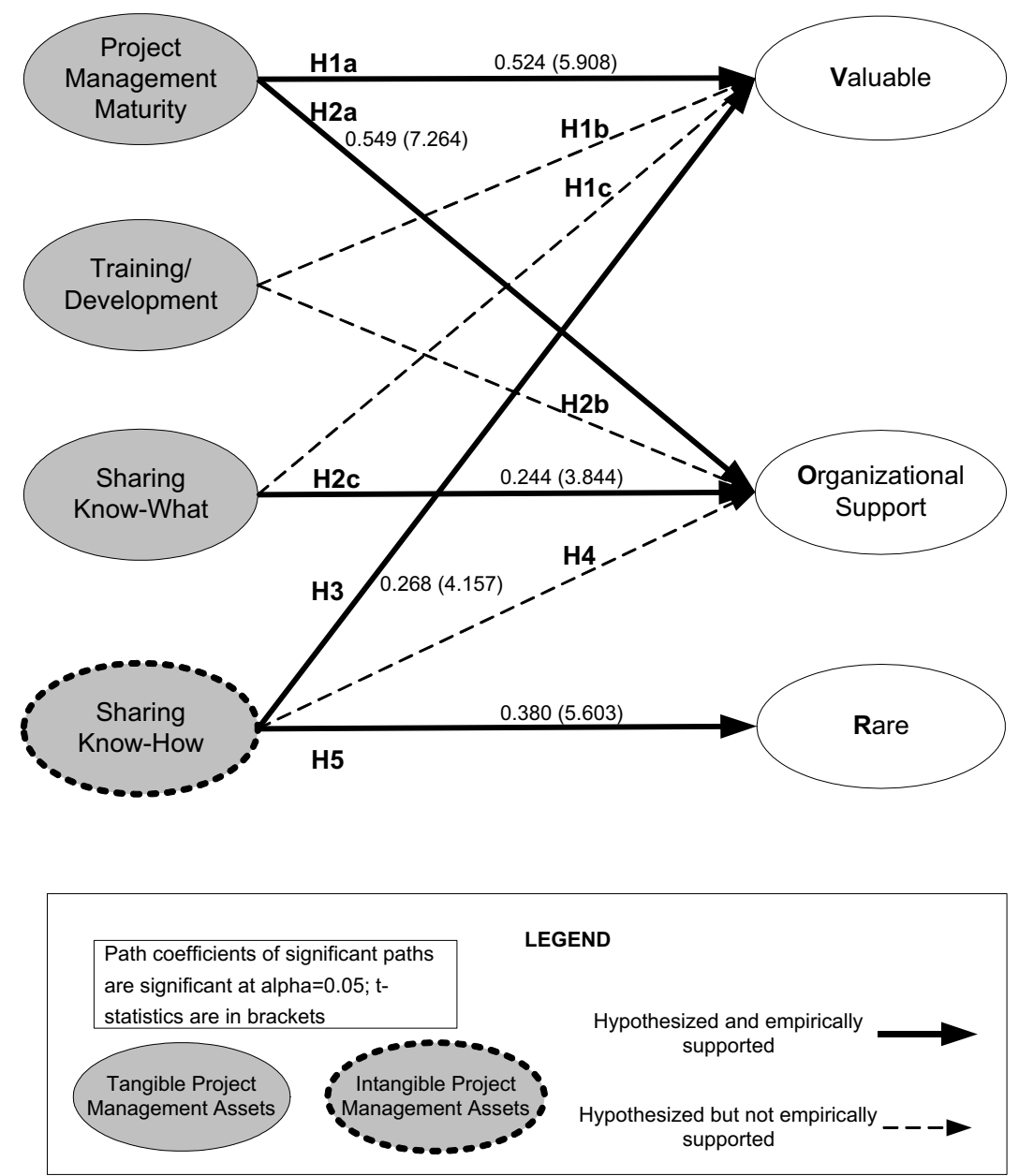

Fig. 2. The structural model.

of explicit knowledge are assets that contribute to process maturity, however, as stand-alone assets they may not contribute to the process being valuable. The relationship among asset factors is worth exploring in more detail through further study.

We find that Project Management Maturity and Sharing Know-What result in Organizational Support, but Training and Development does not. It is possible that budgetary constraints and no immediately visible returns may result in a lack of management support for training and development processes [44]. Again, these findings point to a need to examine the relationship among asset factors.

Sharing Know-How significantly predicts the project management process being Valuable and Rare in keeping with the literature and our conceptual framework, but it did not predict the project management process having Organizational Support. Sharing Know-How predicting the project management process being Rare is an important finding because it supports the hypothesis that intangible assets predict the VRIO characteristic of Rare, which is essential for competitive advantage.

It is of interest that Sharing Know-What significantly predicted the project management process as having Organizational Support, but Sharing Know-How did not. While theory recognizes the importance of intangible assets, it appears from our empirical study that sharing of tacit knowledge is not recognized or is undervalued in current project management practices.

There were no relationships theorized between tangible project management assets (Project Management Maturity,

\section{Table 2}

Fit indices for the structural models

\begin{tabular}{lll}
\hline $\begin{array}{l}\text { Model } \\
\text { fit index }\end{array}$ & $\begin{array}{l}\text { Model presented in } \\
\text { Fig. 2 (based on VRIO } \\
\text { framework) }\end{array}$ & $\begin{array}{l}\text { Comparison case (adding paths } \\
\text { between tangible asset factors and } \\
\text { Rare) }\end{array}$ \\
\hline GFI & 0.969 & 0.973 \\
AGFI & 0.858 & 0.745 \\
RMSR & 0.032 & 0.023 \\
\hline
\end{tabular}


Training and Development, and Sharing Know-What) to the project management process being Rare in keeping with the VRIO literature and our conceptual framework in Fig. 1. We did, however, test a structural model with these links included and verified that these paths were not empirically supported. We also compared the goodness of fit measures for the model with the additional paths between tangible asset factors and rare with our theorized model in Fig. 2. The comparison between the goodness of fit indices is provided in Table 2.

\subsection{Conclusions and implications for practice}

This study was an exploratory examination of project management assets as a source of competitive advantage using the VRIO framework from the Research Based View of the firm and data from an online survey with North American Project Management Institute ${ }^{\circledR}$ members. This research is an important step towards an improved understanding of the elements of tangible and intangible project management assets. In addition, this research is a necessary step towards further analysis of the relationship between these assets and the project management capability of the firm, and a better understanding of project management as a source of competitive advantage.

The VRIO framework suggests that while an investment in tangible assets is important for achieving competitive parity, these assets are not a source of temporary or sustained competitive advantage. While the VRIO framework has been extensively tested empirically, we believe a major contribution is testing it in the project management context. Empirical support of the VRIO framework in the project management context through this research is an important contribution. In addition, this research contributes by underscoring the importance of intangible project management assets in a discipline which has largely been focused on tangible assets. The key finding of this empirical work is that Sharing Know-How, an intangible project management asset factor, significantly predicts the project management process being Rare.

This paper highlights the importance of identifying and managing intangible project management assets for project management practitioners and executives. It is recommended that companies constantly assess their investment in both the tangible and intangible assets that constitute a project management process in order to determine which intangible project management assets should be developed internally to achieve the characteristic of rarity and inimitability.

\section{Limitations and directions for future research}

Since this was an exploratory study, it has led to the identification of several new directions for research. Even though we were able to identify project management factors and VRIO factors and find a significant difference in the contribution of tangible and intangible assets to achiev- ing VRIO characteristics, there is scope to elaborate on the simple VRIO model and to improve the research instrument based on the findings of this study.

The high correlations observed among the asset variables point to the need for extensions of the VRIO framework that explore the mediating influence of one or more asset factors on the relationship between the other asset factors and the outcomes. This exploration is in progress.

The study was also limited by the questionnaire items resulting in an inability to distinguish between the constructs of Rare and Inimitable. We are in the process of addressing this through a redesign of the instrument. There is a need to reconcile the relationships between factors that encompass processes and systems versus factors related to values through more careful definition of survey items.

While the sample size was fair and allowed the researchers to conduct a path model, the limited scale of the study calls for replication and elaboration of findings through a large-scale empirical study.

Potential areas of further study that emerged include an examination of values from an organizational culture and project climate perspective and the concepts of bridging and bonding social capital [45] as sources of intangible assets.

This paper contributes to and bridges two fields, the growing body of research that draws on the Resource Based View of the firm and research on the project management process as a source of competitive advantage. We believe that this convergence is crucial to the future development of the project management discipline and warrants research targeted to both advances in theory and improvements to practice.

\section{Acknowledgements}

This study was supported by Athabasca University, San José State University, the University of Calgary and a grant from the Social Sciences and Research Council of Canada. The authors would like to acknowledge the study participants for completing the survey. The authors would like to thank the reviewers for their helpful feedback.

\section{References}

[1] Brush CG, Greene PG, Hart MM, Haller HS. From initial idea to unique advantage: the entrepreneurial challenge of constructing a resource base. Acad Manage Execut 2001;15(1):64-78.

[2] Teece DJ, Pisano G, Shuen A. Dynamic capabilities and strategic management. Strat Manage J 1997;18(7):509-33.

[3] Amit R, Schoemaker PJH. Strategic assets and organizational rent. Strat Manage J 1993;14(1):33-46.

[4] Eisenhardt K, Santos F. Knowledge-based view: a new theory of strategy? In: Pettigrew A, Thomas H, Whittington R, editors. Handbook of strategy and management. London: Sage Publications; 2000. p. 544.

[5] Kaplan S, Schenkel A, von Krogh G, Weber C. Knowledge-based theories of the firm in strategic management: a review and extension. MIT Sloan working paper 4216-01, 2001. 
[6] Kogut B. The network as knowledge: generative rules and the emergence of structure. Strat Manage J 2000;21(3):405-25.

[7] Nonaka I. A dynamic theory of organizational knowledge creation. Organiz Sci 1994;5(1):14-37.

[8] Rumelt RP, Schendel DE, Teece DJ. Fundamental issues in strategy. In: Rumelt RP, Schendel DE, Teece DJ, editors. Fundamental issues in strategy. Cambridge, MA: Harvard Business School Press; 1994. p. 9-47.

[9] Foss NJ, editor. Resources, firms and strategies: a reader in the resource-based perspective, vol. 1. Oxford, UK: Oxford University Press; 1997. p. 378.

[10] Barney JB. Gaining and sustaining competitive advantage. 2nd ed. Upper Saddle River, NJ: Prentice-Hall, Inc.; 2002. p. 600.

[11] Barney JB. Firm resources and sustained competitive advantage. J Manage 1991;17(1):99-120.

[12] Wright PM, Dunfield BB, Snell SA. Human resources and the resource-based view of the firm. J Manage 2001;27(6):701-21.

[13] Lockett A, Thompson S. The resource-based view and economics. J Manage 2001;27(6):723-54.

[14] Alvarez SA, Busenitz LW. The entrepreneurship of resource-based theory. J Manage 2001;27(6):755-75.

[15] Peng MW. The resource-based view and international business. J Manage 2001;27(6):803-29.

[16] Srivastava RK, Fahey L, Christensen HK. The resource-based view and marketing: the role of market-based assets in gaining competitive advantage. J Manage 2001;27(6):777-802.

[17] Packendorff J. Inquiring into the temporary organization: new directions for project management. Scand J Manage 1995;11(4):319-33.

[18] Koskela L, Howell G. The underlying theory of project management is obsolete. In: Frontiers of project management research and application. Seattle, WA: Project Management Institute; 2002.

[19] DeFillippi RJ, Arthur MB. Paradox in project-based enterprise: the case of film making. California Manage Rev 1998;40(2):125-39.

[20] Fernie S, Green SD, Weller SJ, Newcombe R. Knowledge sharing: context, confusion, and controversy. Int $\mathrm{J}$ Project Manage 2003;21(3):177-87.

[21] PMI. A guide to the project management body of knowledge (PMBOK ${ }^{\circledR}$ guide), 3rd ed. PMBOK, I. Project Management Institute, vol. 1. 2004, Project Management Institute, Newtown Square, PA, 388.

[22] Ulri B, Ulri D. Project management in North America: stability of the concepts. Project Manage J 2000;31(3):33-43.

[23] Kloppenborg T, Opfer W. The current state of project management research: trends, interpretations, and predictions. Project Manage J 2002;33(2):5-18.

[24] Jugdev K. Developing and sustaining project management as a strategic asset: a multiple case study using the resource-based view. Unpublished $\mathrm{PhD}$ thesis. Project Management Specialization. University of Calgary, Calgary, AB, 2003.

[25] Morris PWG. Updating the project management bodies of knowledge. Project Manage J 2001;32(3):21-30.

[26] Crawford JK. The strategic project office: a guide to improving organizational performance, 1st ed. PM Practices Book Series, Centre for Business Practices, vol. 1. Marcel Dekker, Inc., New York, New York, 2002. p. 367.

[27] Rad PF, Levin G. The advanced project management office: a comprehensive look at function and implementation, 1st ed., vol. 1. Boca Raton, FL: CRC Press; 2002. p. 224.

[28] Kerzner H. Strategic planning for a project office. Project Manage J 2003;34(2):13-25.

[29] Ibbs CW, Kwak YH. Assessing project management maturity. Project Manage J 2000;31(1):32-43.

[30] ESI-International. ESI-International. [Internet] 22 November 2001 [cited 20 November 2002]. Available from: http://www.esi-intl. com/.

[31] Hartman FT. Don't park your brain outside: a practical guide to improving shareholder value with SMART project management, 1st ed. Project Management Institute, Upper Darby, Pennsylvania, 2000. p. 407.

[32] MicroFrame. Project management maturity model. [Internet] 1 October 2001 [cited 20 November 2002]. Available from: http:// www.microframe.com/.

[33] Jugdev K, Thomas J. Project management maturity models: the silver bullets of competitive advantage. Project Manage J 2002;33(4):4-14.

[34] Dillman DA, Sinclair MD, Clark JR. Effects of questionnaire length, respondent-friendly design, and a difficult question on response rates for occupant-addressed census mail surveys. Public Opinion Quart 1993;57(3):289-304.

[35] Fowler FJ. How unclear terms affect survey data. Public Opinion Quart 1992;56(2):218-31.

[36] Couper MP, Traugott MW, Lamias MJ. Web survey design and administration. Public Opinion Quart 2001;65(2):230-53.

[37] Tabachnick BG, Fidell LS. Using multivariate statistics, fourth ed., vol. 1. Northridge, CA: Harper Collins College Publishers; 2000. p. 880.

[38] Conway JM, Huffcutt AI. A review and evaluation of exploratory factor analysis practices in organizational research. Organiz Res Meth 2003;6(2):147-68.

[39] Hair JF, Anderson RE, Tatham RL, Black WC. Multivariate data analysis. 5th ed. Upper Saddle River, NJ: Prentice-Hall, Inc.; 1998. p. 730 .

[40] Nunnally JC. Psychometric theory. 2nd ed. New York: McGraw-Hill; 1978.

[41] Ray G, Barney JB, Muhanna WA. Capabilities, business processes, and competitive advantage: choosing the dependent variable in empirical tests of the resource-based view. Strategic Manage J 2004;25(1):23-37.

[42] Jugdev K, Mathur G. Project management elements as strategic assets: preliminary findings. Manage Res News 2006;29(6):604-17.

[43] Rowntree D. In: Lasser J, editor. Statistics without tears: A primer for non-mathematicians, 2nd ed., vol. 1. Boston, MA: Allyn and Bacon; 2004. p. 193.

[44] McClernon T. Rivals to systematic training. Adv Develop Human Resour 2006;8(4):442-60.

[45] Lesser EL, editor. Knowledge and social capital: foundations and applications, vol. 1. Boston, MA: Butterworth \& Heinemann; 2000. p. 323. 